\title{
NITROGEN MANGEMENT UNDER DIFFERENT COMPOST LEVELS FOR LETTUCE PLANT GROWN IN COCONUT FIBER
}

\author{
FARAG, A. A. ${ }^{1}$, M. A. A. ABDRABBO ${ }^{1}$ AND E. M. ABD EL-MONIEM ${ }^{2}$ \\ 1. Central Laboratory for Agricultural Climate, ARC, Dokki, Giza \\ 2. Soil Dept., Fac. Agric., Ain Shams Univ., Cairo
}

(Manuscript received 23 March 2009)

\begin{abstract}
Two experiments were conducted at the roof of Central Laboratory for Agricultural Climate, Dokki, Giza-Egypt. Two lettuce types (Lactuca sativa L.) iceberg and romaine were transplanted at October during the two seasons (2006 and 2007) into white polyethylene container filled with coconut fiber media. The experiments aimed to study the effect of three nitrogen levels (50, 100 and $150 \mathrm{ppm}$ ) applied by fertigation and three compost levels $(0,2$ and $4 \%$ by volume). The experimental design was a completely randomized factorial design with three replications. Using different nitrogen and compost levels were affected vegetative growth, nutrients content $(\mathrm{N}, \mathrm{P}, \mathrm{K}, \mathrm{Ca}, \mathrm{Mg}$ and $\mathrm{NO}_{3}$ ) and yield. The obtained results indicated that the increasing nitrogen level up to $150 \mathrm{ppm}$ significantly increased plant height, number of leaves per plant, dry weight and yield. Compost $4 \%$ level gave the highest vegetative growth and yield comparing with the other compost treatments. The highest nitrogen level (150ppm) combined with compost $4 \%$ increased vegetative growth and yield significantly. On the other hand, $50 \mathrm{ppm}$ nitrogen gave the highest nitrogen use efficiency (NUE) and the least value of nitrate content in leaves followed by $100 \mathrm{ppm}$. The highest nitrogen level (150ppm) led to increase nitrate content over the healthy save line with different compost levels.

Key words: Polyethylene container - Nitrogen use efficiencyNitrate- Content-Soilless
\end{abstract}

\section{INTRODUCTION}

Vegetables are the group of foods which makes the greatest contribution to nitrate consumption and leafy crops such as lettuce and spinach are particularly likely to contain high levels of nitrates. An EU regulation has set limits of $4,500 \mathrm{mg} \cdot \mathrm{kg}-1$ of nitrate in the fresh product for lettuce harvested from November 1 to March 31 and 3,500 mg kg-1 from April 1 to October 31(Byrne et al., 2001).

Lettuce (Lactuca sativa L.) is a plant of considerable agricultural and economic interest but as a leafy vegetable it accumulates large quantities of nitrate especially when grown in high $\mathrm{NO}_{3}-\mathrm{N}$ availability and low radiation. The accumulation of nitrate in plants depends on their genetic characteristics as well as on many environmental 
factors such as nitrogen supply for example replacement a part of $\mathrm{NO}_{3}-\mathrm{N}$ concentration by urea or methods of application, light intensity, photoperiod, temperature or water supply (Zhu et al., 2000).

Large inputs of mineral fertilizer nitrogen $(\mathrm{N})$ are routinely used to maintain the yield and quality of crops. Nitrogen not recovered by crops can pollute adjacent terrestrial and aquatic habitats. This can cause a reduction in biodiversity since species that are characteristic of infertile habitats do not tend to thrive following nutrientenrichment (Gul, et al., 2003).

Nitrogen is one of the most important mineral nutrients determining plant growth and crop yield. Its effects are associated with leaf area growth and photosynthetic rate (Pinheiro-Henriques \& Marcellis, 2000, Pons \& Westbeek, 2004).

The particular structure of coconut fibers and their physical and chemical properties, make them suitable for container media purposes. In fact the use of coconut fiber in European greenhouse production is well accepted as new technology. Coir contains equal portions of lignin and cellulose and is rich in potassium and the micronutrients $\mathrm{Fe}, \mathrm{Mn}, \mathrm{Zn}$, and $\mathrm{Cu}$. Due to the high potassium content of the media a reduction in potassium fertilization has been shown to produce beneficial results (Gul, et al., 2003).

Compost contains many essential nutrients and improves soil physical and chemical properties. It without a doubt is a valuable product as compost improves soil organic matter content, nutrient availability soil aeration, and water holding capacity, and reduces soil bulk density. Compost, if properly prepared, is beneficial to the productivity of field and container crops (Zhu et al., 2000)

The aims of this study was determine the save nitrogen level to growing lettuce plants in soilless culture by replacing part of mineral fertilizer by organic. On the other hand, improve coconut media properties by using compost.

\section{MATERIALS AND METHODS}

Two experiments were carried out in the two successive seasons at 2006 and 2007 at roof of Central Laboratory for Agricultural Climate Dokki, Agricultural Research Center, located at Giza governorate Egypt. Each experiment included three nitrogen levels 50, 100 and $150 \mathrm{ppm}$ applied by fertigation system, which were the combinations with three compost levels 0,2 and $4 \%$ volume of medium. Seeds of iceberg lettuce (Lactuca sativa var. capitata L.) cv. 'Vanity' and romaine lettuce (Lactuca sativa var. longifolia L.) cv. 'Balady' were sown at 15 and 18 August. Dates of transplanting were Oct. 5 and 9 of 2006 and 2007, for the first and the second seasons, respectively. Lettuce grown into white polyethylene container of $0.60 \mathrm{~m}$ 
Length $\times 0.25 \mathrm{~m}$ Width $\times 0.25 \mathrm{~m}$ height, filled with 30 liters coconut fiber. Chemical and physical properties of coconut fiber are tabulated in Table (1). Each container contained three plants. Experiment design was a split plot with three replications where nitrogen fertilizer levels were distributed in the main plot and compost levels allocated in sub plots. Chemical properties of compost are tabulated in Table (2).Analysis of data was done by computer, using ANOVA program for statistical analysis. The differences among means for all traits were tested for significance at 5 $\%$ level according to Waller and Duncan (1969). All other agriculture practices of cultivation were performed as recommended by the Egyptian Ministry of Agriculture. Fresh and dry weights of individual plant were taken at 55- day from the transplanting date, samples of three plants randomly harvested. Total dry weight was determined after oven-drying the samples at $75{ }^{\circ} \mathrm{C}$ for 48 hours. $\mathrm{N}, \mathrm{P}$ and $\mathrm{K}$ were determined in leaf. Samples which were dried at $70{ }^{\circ} \mathrm{C}$ in an air forced oven for 48 hour. Dried leaves were digested in $\mathrm{H}_{2} \mathrm{SO}_{4}$ and the fallowing mineral contents were estimated (phosphorous and potassium) in the acid digested solution by colorimetric method (ammonium molybdate) using spectrophotometer and flame photometer (Chapman and Pratt, 1961). Nitrogen uptake was derived from dry weight in which total nitrogen concentration was determined by a micro-Kjeldahl method (Bremner and Mulvaney, 1982). Nitrogen use efficiency (NUE) was calculated as the yield obtained from the $\mathrm{N}(\mathrm{Yn})$ fertilized plot minus control $(\mathrm{Yc})$, divided by a unit weight of the applied fertilizer (Nw for nitrogen).

\section{NUE $=(\mathbf{Y n}-\mathbf{Y c}) / \mathbf{N w}$}

Table 1. Chemical properties of the coconut fiber of the experiment were analyzed before cultivation.

\begin{tabular}{|c|c|c|c|c|c|c|c|c|c|c|c|c|c|}
\hline EC & \multirow[t]{3}{*}{$\mathrm{pH}$} & & & & & & & & & $\mathrm{N}$ & C & $\mathrm{C} / \mathrm{N}$ & O.M \\
\hline \multirow{2}{*}{$\begin{array}{l}\mathrm{dS} \\
\mathrm{m}^{-1}\end{array}$} & & \multicolumn{4}{|c|}{ Cations Meq/L } & \multicolumn{4}{|c|}{ Anions $\mathrm{Meq} / \mathrm{L}$} & \multirow[t]{2}{*}{$\%$} & \multirow[t]{2}{*}{$\%$} & \multirow[t]{2}{*}{$\%$} & \multirow[t]{2}{*}{$\%$} \\
\hline & & $\mathrm{Ca}^{++}$ & $\mathrm{Mg}^{++}$ & $\mathrm{Na}^{+}$ & $\mathrm{K}^{+}$ & $\mathrm{CO}^{---}$ & $\mathrm{HCO}^{-}$ & $\mathrm{Cl}^{-}$ & $\mathrm{SO}^{--}$ & & & & \\
\hline 1.23 & 6.48 & 2.20 & 3.14 & 6.30 & 1.46 & 0.0 & 2.10 & 16.3 & 6.51 & 0.01 & 22.30 & 78.4 & 91.3 \\
\hline
\end{tabular}

Table 2. Chemical properties of the compost used in the experiment were analyzed before cultivation.

\begin{tabular}{|c|c|c|c|c|c|c|c|c|c|c|c|c|c|}
\hline EC & \multirow[t]{3}{*}{$\mathrm{pH}$} & & & & & & & & & $\mathrm{N}$ & C & $\mathrm{C} / \mathrm{N}$ & O.M \\
\hline \multirow{2}{*}{$\begin{array}{l}\mathrm{dS} \\
\mathrm{m}^{-1}\end{array}$} & & \multicolumn{4}{|c|}{ Cations Meq/L } & \multicolumn{4}{|c|}{ Anions $\mathrm{Meq} / \mathrm{L}$} & \multirow[t]{2}{*}{$\%$} & \multirow[t]{2}{*}{$\%$} & \multirow[t]{2}{*}{$\%$} & \multirow[t]{2}{*}{$\%$} \\
\hline & & $\mathrm{Ca}^{++}$ & $\mathrm{Mg}^{++}$ & $\mathrm{Na}^{+}$ & $\mathrm{K}^{+}$ & $\mathrm{CO}^{--}$ & $\mathrm{HCO}^{-}$ & $\mathrm{Cl}^{-}$ & $\mathrm{SO}^{--}$ & & & & \\
\hline 7.95 & 7.39 & 19.0 & 51.6 & 48.4 & 1.05 & 0.40 & 3.1 & 34 & 38.15 & 0.52 & 4.94 & 15.41 & 9.88 \\
\hline
\end{tabular}




\section{RESULTS AND DISCUSSION}

\section{Vegetative growth}

The effect of different nitrogen and compost levels on vegetative growth characters presented in Tables ( $3 \& 4$ ). Regarding the effect of different nitrogen treatments, data showed that using 150 ppm nitrogen level increased lettuce plant height, number of leaves and dry weight significantly followed by $100 \mathrm{ppm}$ treatment. The lowest vegetative growth was obtained by $50 \mathrm{ppm}$ treatment during the two studied seasons.

The compost levels had same response on vegetative growth indicated that $4 \%$ compost had the highest vegetative growth followed by $2 \%$ compost with significant difference between them with the two lettuce types.

Regarding the interaction effect between different nitrogen and compost levels, data illustrated that the highest vegetative growth characters obtained by using $150 \mathrm{ppm}$ nitrogen level combined with $4 \%$ compost followed by $100 \mathrm{ppm}$ nitrogen level with $4 \%$ compost. On the other hand, the lowest vegetative growth characters were obtained by using $50 \mathrm{ppm}$ nitrogen level treatment with $0 \%$ compost with the two lettuce types.

Nitrogen is one of the most important mineral nutrients determining plant growth this result agree with Broadley et al. (2000) and Pons and Westbeek (2004) who found that reducing $\mathrm{N}$ supply to lettuce considerably reduced plant growth. Reductions in the plant growth of $\mathrm{N}$-limited plants correlate with decreases in leaf area, fresh and dry weight a reallocation of $C$ from shoots to roots and a reduction in net $C$ assimilation. Alphonse and Saad (2000) reported that applying organic manure to growing media of cucumber plant significantly increased plant height, number of leaves and dry weight. They mentioned that increasing compost rate from 40 to 60 $\mathrm{m}^{3}$ / fed. increased plant growth of potato. Generally, using mineral fertilizer exhibited highest value of fresh and dry weight of lettuce leaves. When the organic manure as chicken and pigeon manure was supplemented with inorganic fertilizer, fresh and dry weight increased comparing with other treatments (Abd-Elmoniem et al., 2001).

\section{Yield (head and leanes fresh weight)}

The effect of different treatments on lettuce yield was presented in Tables (5 \& 6). Referring the effect of different nitrogen levels, data showed that using 150ppm nitrogen level increased head weight significantly followed by $100 \mathrm{ppm}$ nitrogen level, comparing with $50 \mathrm{ppm}$ nitrogen level.

Regarding the effect of different compost levels on yield, data showed that the highest yield weight obtained by $4 \%$ compost followed by $2 \%$ compost with significant 
difference between them. The lowest yield was obtained by $0 \%$ compost with the two lettuce types.

Regarding the interaction effect between different nitrogen levels and compost, data showed that using 150ppm nitrogen level combined with4\%compost increased plant fresh weight (yield) significantly followed by 100ppm nitrogen level combined with $4 \%$ compost with iceberg lettuce, but there were no significantly differences between them with romaine lettuce. The lowest yield was obtained by 50ppm nitrogen level plus $0 \%$ compost with the two lettuce types.

The increases in yield might be due to the increased utilization of $\mathrm{N}$ fertilizer in stimulating meristimatic activities. The accumulation of synthesized metabolites resulted in high dry matter accumulation and finally high yield. The obtained results are a good line with those reported by (Pinheiro Henriques \& Marcellis, 2000). On the other hand, increasing manure level up to $4 \%$ of the coconut fiber media led to increase the yield, this data agreed with Yuri et al. (2004) who concluded that using organic compost increased lettuce yield and commercial quality of crisp head lettuce. On the other hand, coconut fiber media is low water holding capacity media this led to decrease the humidity in rooting zone and decrease plant water and nutrient uptake. Applying compost into coconut fiber was improved plant growth and yield due to the increase water and nutrient uptake (Gul et al., 2003).

\section{Nitrogen Use Efficiency (NUE)}

Data of nitrogen use efficiency which is defined as the economic production obtained per unit of nitrogen applied is presented in Tables (7\&8). It is evident from the data obtained that the highest NUE was obtained by $50 \mathrm{ppm}$ nitrogen level followed by $100 \mathrm{ppm}$ nitrogen level with significant difference between them. The lowest NUE was obtained by 150 ppm nitrogen level.

Referring to NUE under different compost levels, data revealed that increasing compost level up to $4 \%$ led to increase NUE for the two lettuce types during the two successive seasons.

Referring the interaction effect between nitrogen and compost levels, the lowest nitrogen levels(50ppm)I combined with $4 \%$ compost gave the highest NUE followed by $50 \mathrm{ppm}$ nitrogen level combined with $2 \%$ compost with the two lettuce types (iceberg and romaine).

These results agreed with (Pons and Westbeek. 2004) who found that maximizing the nitrogen-use efficiency of crop production can be achieved by (i) optimizing the supply of $\mathrm{N}$ to meet the requirements of a crop during growth and development or (ii) by growing $\mathrm{N}$-efficient crop genotypes. There is therefore much advantage to be derived from using economic rate that will enhance higher nitrogen 
use efficiency and maximize production Based on the value of increased nitrogen input, the decline observed in NUE (Marschner, 1995).

\section{Mineral contents}

According to the effect of nitrogen levels, data in Tables (9\&10) showed that using 150ppm nitrogen led to increase N, P, K, Ca and Mg\% significantly in lettuce leaves followed by $100 \mathrm{ppm}$ nitrogen with significant difference between them. The lowest $\mathrm{N}, \mathrm{P}$ and $\mathrm{K} \%$ was obtained by $50 \mathrm{ppm}$ nitrogen.

The effect of applied compost levels on N, P, K, Ca and Mg\% in lettuce leaves. The highest $\mathrm{N}, \mathrm{P}, \mathrm{K}, \mathrm{Ca}$ and $\mathrm{Mg} \%$ was observed by $4 \%$ compost followed by $2 \%$ compost with significant difference between them. The lowest $\mathrm{N}, \mathrm{P}, \mathrm{K}, \mathrm{Ca}$ and $\mathrm{Mg} \%$ was obtained by $0 \%$ compost.

The interaction effect between nitrogen and compost, data showed that using 150ppm nitrogen combined with $4 \%$ compost increased $\mathrm{N}, \mathrm{P}, \mathrm{K}, \mathrm{Ca}$ and $\mathrm{Mg}$ percentage. The lowest $\mathrm{N}, \mathrm{P}, \mathrm{K}, \mathrm{Ca}$ and $\mathrm{Mg} \%$ proceeded by $50 \mathrm{ppm}$ nitrogen with $0 \%$ compost with the two lettuce types. These results are in agreement with Gul et al. (2003) who reported that the uptake of $N, P$, and $K$ increased with increasing $N$ concentration in the nutrient solution. The same user reported that the protein, phosphorus, potassium, calcium and magnesium contents in lettuce leaves increased with the doses of organic compost. He reported that mixing the recommended amounts of organic manure into substrate prior to planting could be a sufficient nutrient source for lettuce plants. These results can be related to higher water holding capacity of fiber coconut with compost compared to fiber coconut only.

\section{Nitrate Contents}

Data in Tables (9\&10) indicated that $\mathrm{NO}_{3}-\mathrm{N}$ in dry weight and $\mathrm{NO}_{3}-\mathrm{N}$ as a percentage from total nitrogen, affected significantly by nitrogen and compost levels in lettuce plants. Nitrate contents in dry weight recorded the least values with $50 \mathrm{ppm}$ nitrogen in comparison with 100 and 150 ppm nitrogen levels with both lettuce types during the two tested seasons. Regarding the compost treatments $4 \%$ compost level gave the highest nitrate content with the both lettuce types.

The interaction between nitrogen and compost recorded the least value with $0 \%$ compost combined with $50 \mathrm{ppm}$ nitrogen in during the two successive seasons.

Accumulation of nitrates in lettuce has been shown to be affected by the soil texture, amount of fertilizer- $\mathrm{N}$, the timing of fertilizer- $\mathrm{N}$ release, compost application level, the light intensity and duration. In most types of lettuce, including the romaine type had the highest concentration of nitrates and is normally observed in the external leaves (Santamaria et al., 2002 and Abu- Rayyan et al., 2004). The capability to transform inorganic nitrogen into organic nitrogen (determined by subtracting $\mathrm{NO}_{3}-\mathrm{N}$ from total $\mathrm{N}$ ) was affected by plant genotypes and it decreased with increasing $\mathrm{N}$ 
availability and uptake. Some authors consider this as luxury consumption and believe plants absorbing more nutrients than needed for growth can use this reserve to assure growth even when their availability in the cultivation substrate decreases (AbuRayyan et al., 2004). On the other hand, Rocket salad plants can absorb $\mathrm{NO}_{3}$ very quickly (Santamaria et al., 2002), as confirmed in the present research results, $\mathrm{NO}_{3}$ concentration in leaves was much higher than in the nutrient solution. The nitrate content in lettuce tissues was very low when organic manure was used for fertilizing the plants compared to those fertilized by inorganic fertilizer ( Abd-Elmoniem et al., 2001). Furthermore, Nitrate content in roots, stems, and leaves increased linearly with Nitrogen and manure application (Pôrto, 2008). On the other hand, Marschner (1995) reported that nitrate accumulation by plants is observed when plant nitrogen uptake exceeds the assimilation capacity. The surplus of $\mathrm{N}$ inside the plant is then stored as nitrate in the cell vacuoles. Thus, the highest nitrate concentration in plants observed when $\mathrm{N}$ was supplied using a mineral source compared to the organic fertilization is probably due to the prompt $\mathrm{N}$ availability in soluble fertilizers in the first, causing $\mathrm{N}$ abundance in the soil solution, in opposition to the slow nutrient release by the latter.

\section{Yield vs. nitrate content}

The relationship between yield and nitrate content for both lettuce types during the two growing seasons was illustrated in Fig. (1, 2, 3 and 4)

The highest lettuce yield was observed by the highest nitrogen and compost levels compared to the other treatment while the highest nitrogen (150ppm) treatments recorded the values over the safe level (1000 ppm in the dry weight) regardless compost level, $\mathrm{NO}_{3}-\mathrm{N}$ contents in lettuce plant under the safe level ppm $\mathrm{NO}_{3}-\mathrm{N}$ in dry weight with 50 and 100ppm nitrogen level with different compost levels. These results were agreed with Marschner (1995) who found that increasing nitrogen dose in nutrient solution for lettuce plants led to increase nitrate content over the health safe level in dry weight .

\section{CONCLUSION}

Despite using $150 \mathrm{ppm}$ nitrogen led to increase lettuce yield compared to $100 \mathrm{ppm}$, nitrate content in the lettuce leaves exceed the save line range in the 150 $\mathrm{ppm}$ nitrogen level in the nutrient solution comparing with $100 \mathrm{ppm}$. We recommended using $100 \mathrm{ppm}$ nitrogen level combined with $4 \%$ compost. Coconut fiber substrates can be used in soilless culture in Egypt by mixed with compost to improve media properties such as water holding capacity and cation exchange capacity this led to improve plant growth and yield.

Table 3. Effect of different applied nitrogen and compost levels on plant height, number of leaves and plant dry weight for iceberg lettuce plants during the 2006 and 2007 seasons.

\begin{tabular}{|c|c|c|}
\hline 2006 season & 2007 season \\
\hline
\end{tabular}




\begin{tabular}{|c|c|c|c|c|c|c|c|c|}
\hline $\begin{array}{c}\text { Nitrogen } \\
\text { levels }\end{array}$ & $50 \mathrm{ppm}$ & $100 \mathrm{ppm}$ & $150 \mathrm{ppm}$ & Mean A & $50 \mathrm{ppm}$ & $100 \mathrm{ppm}$ & $150 \mathrm{ppm}$ & Mean A \\
\hline Compost & \multicolumn{4}{|c|}{ Plant height(cm) } & \multicolumn{4}{|c|}{ Plant height(cm) } \\
\hline $0 \%$ & $12.6 \mathrm{G}$ & $13.7 \mathrm{~F}$ & $15.4 \mathrm{D}$ & $13.9 \mathrm{C}$ & $13.1 \mathrm{E}$ & $14.3 \mathrm{D}$ & $16.1 \mathrm{C}$ & $14.5 \mathrm{~B}$ \\
\hline $2 \%$ & $13.8 \mathrm{~F}$ & $17.6 \mathrm{C}$ & $18.8 \mathrm{~B}$ & $16.7 \mathrm{~B}$ & $14.4 \mathrm{D}$ & $18.3 \mathrm{~B}$ & $18.1 \mathrm{~B}$ & $16.9 \mathrm{AB}$ \\
\hline $4 \%$ & $15.1 \mathrm{D}$ & $18.9 \mathrm{~B}$ & $20.1 \mathrm{~A}$ & $18.0 \mathrm{~A}$ & $14.5 \mathrm{D}$ & $18.2 \mathrm{~B}$ & $19.3 \mathrm{~A}$ & $17.3 \mathrm{~A}$ \\
\hline \multirow[t]{2}{*}{ Mean B } & $13.8 \mathrm{C}$ & $16.7 \mathrm{~B}$ & $18.1 \mathrm{~A}$ & & $14.0 \mathrm{~B}$ & 16.9AB & $17.8 \mathrm{~A}$ & \\
\hline & \multicolumn{4}{|c|}{ Number of leaf } & \multicolumn{4}{|c|}{ Number of leaf } \\
\hline $0 \%$ & $29.2 \mathrm{~F}$ & $32.5 \mathrm{E}$ & $35.7 \mathrm{D}$ & $32.4 \mathrm{C}$ & $30.4 \mathrm{G}$ & $33.9 \mathrm{E}$ & $37.2 \mathrm{D}$ & $33.8 \mathrm{C}$ \\
\hline $2 \%$ & $31.2 \mathrm{EF}$ & $40.6 \mathrm{C}$ & $44.2 \mathrm{BC}$ & $38.6 \mathrm{~B}$ & $32.5 \mathrm{~F}$ & $42.3 \mathrm{C}$ & $42.8 \mathrm{BC}$ & $39.2 \mathrm{~B}$ \\
\hline $4 \%$ & 34.4 DE & $45.5 \mathrm{~B}$ & $48.7 \mathrm{~A}$ & $42.8 \mathrm{~A}$ & $33.1 \mathrm{EF}$ & $43.9 \mathrm{~B}$ & $46.9 \mathrm{~A}$ & $41.3 \mathrm{~A}$ \\
\hline \multirow[t]{2}{*}{ Mean B } & $31.6 \mathrm{C}$ & $39.5 \mathrm{~B}$ & $42.8 \mathrm{~A}$ & & $32.0 \mathrm{C}$ & $40.0 \mathrm{~B}$ & $42.3 \mathrm{~A}$ & \\
\hline & \multicolumn{4}{|c|}{ Head dry weight (g) } & \multicolumn{4}{|c|}{ Head dry weight (g) } \\
\hline $0 \%$ & $15.0 \mathrm{I}$ & $23.9 \mathrm{H}$ & $26.8 \mathrm{~F}$ & $21.9 \mathrm{C}$ & $15.6 \mathrm{G}$ & $24.9 \mathrm{~F}$ & $27.9 \mathrm{D}$ & $22.8 \mathrm{C}$ \\
\hline $2 \%$ & $24.5 \mathrm{G}$ & $32.9 \mathrm{D}$ & $35.9 \mathrm{C}$ & $31.1 \mathrm{~B}$ & $25.5 \mathrm{EF}$ & $34.3 \mathrm{C}$ & $34.6 \mathrm{C}$ & $31.4 \mathrm{~B}$ \\
\hline $4 \%$ & $27.3 \mathrm{~F}$ & $39.6 \mathrm{~B}$ & $41.5 \mathrm{~A}$ & $36.1 \mathrm{~A}$ & $26.3 \mathrm{E}$ & $38.2 \mathrm{~B}$ & $40.1 \mathrm{~A}$ & $34.8 \mathrm{~A}$ \\
\hline Mean B & $22.2 \mathrm{C}$ & $32.1 \mathrm{~B}$ & $34.7 \mathrm{~A}$ & & $22.4 \mathrm{C}$ & $32.46 \mathrm{~B}$ & $34.2 \mathrm{~A}$ & \\
\hline
\end{tabular}

Table 4. Effect of different applied nitrogen and compost levels on plant height, number of leaves and plant dry weight for romaine lettuce plants during the 2006 and 2007 seasons.

\begin{tabular}{|c|c|c|c|c|c|c|c|c|}
\hline \multirow{3}{*}{$\begin{array}{r}\begin{array}{r}\text { Nitrogen } \\
\text { levels }\end{array} \\
\text { Compost }\end{array}$} & \multicolumn{4}{|c|}{2006 season } & \multicolumn{4}{|c|}{2007 season } \\
\hline & $50 \mathrm{ppm}$ & $100 \mathrm{ppm}$ & $150 \mathrm{ppm}$ & Mean A & $50 \mathrm{ppm}$ & $100 \mathrm{ppm}$ & $150 \mathrm{ppm}$ & Mean A \\
\hline & \multicolumn{4}{|c|}{ Plant height $(\mathrm{cm})$} & \multicolumn{4}{|c|}{ Plant height $(\mathrm{cm})$} \\
\hline $0 \%$ & $22.4 \mathrm{H}$ & $28.3 \mathrm{~F}$ & $33.8 \mathrm{D}$ & $28.2 \mathrm{C}$ & $21.6 \mathrm{H}$ & $27.3 \mathrm{~F}$ & $32.6 \mathrm{E}$ & $27.2 \mathrm{C}$ \\
\hline $2 \%$ & $26.4 \mathrm{G}$ & $33.6 \mathrm{D}$ & $38.4 \mathrm{C}$ & $32.8 \mathrm{~B}$ & $25.4 \mathrm{G}$ & $35.8 \mathrm{D}$ & $40.9 \mathrm{C}$ & $34.0 \mathrm{~B}$ \\
\hline $4 \%$ & $31.68 \mathrm{E}$ & $40.3 \mathrm{~B}$ & $46.0 \mathrm{~A}$ & $39.3 \mathrm{~A}$ & 33.7 DE & $43.9 \mathrm{~B}$ & $49.6 \mathrm{~A}$ & $42.4 \mathrm{~A}$ \\
\hline \multirow[t]{2}{*}{ Mean B } & $26.8 \mathrm{C}$ & $34.1 \mathrm{~B}$ & $39.4 \mathrm{~A}$ & & $26.9 \mathrm{C}$ & $35.7 \mathrm{~B}$ & $41.0 \mathrm{~A}$ & \\
\hline & \multicolumn{4}{|c|}{ Number of leaf } & \multicolumn{4}{|c|}{ Number of leaf } \\
\hline $0 \%$ & $11.9 \mathrm{G}$ & $18.2 \mathrm{E}$ & $23.1 \mathrm{D}$ & $17.7 \mathrm{C}$ & $11.4 \mathrm{H}$ & $17.5 \mathrm{~F}$ & 22.3 DE & $17.1 \mathrm{C}$ \\
\hline $2 \%$ & $15.3 \mathrm{~F}$ & $22.1 \mathrm{DE}$ & $27.2 \mathrm{~B}$ & $21.5 \mathrm{~B}$ & $14.7 \mathrm{G}$ & $23.5 \mathrm{D}$ & $29.6 \mathrm{~B}$ & $22.6 \mathrm{~B}$ \\
\hline $4 \%$ & $18.7 \mathrm{E}$ & $25.5 \mathrm{C}$ & $35.7 \mathrm{~A}$ & $26.6 \mathrm{~A}$ & $19.9 \mathrm{E}$ & $27.2 \mathrm{C}$ & $38.1 \mathrm{~A}$ & $28.4 \mathrm{~A}$ \\
\hline \multirow[t]{2}{*}{ Mean B } & $15.3 \mathrm{C}$ & $21.9 \mathrm{~B}$ & $28.7 \mathrm{~A}$ & & $15.3 \mathrm{C}$ & $22.7 \mathrm{~B}$ & $30.0 \mathrm{~A}$ & \\
\hline & \multicolumn{4}{|c|}{ Head dry weight $(\mathrm{g})$} & \multicolumn{4}{|c|}{ Plant dry weight $(\mathrm{g})$} \\
\hline $0 \%$ & $21.1 \mathrm{~F}$ & $32.8 \mathrm{D}$ & 44.7BC & $32.9 \mathrm{C}$ & $20.3 \mathrm{G}$ & $31.6 \mathrm{EF}$ & $43.1 \mathrm{D}$ & $31.7 \mathrm{C}$ \\
\hline $2 \%$ & $26.5 \mathrm{E}$ & $45.4 \mathrm{~B}$ & $55.4 \mathrm{AB}$ & $42.4 \mathrm{~B}$ & $25.5 \mathrm{~F}$ & $48.4 \mathrm{C}$ & $59.6 \mathrm{~B}$ & $44.5 \mathrm{~B}$ \\
\hline $4 \%$ & 31.3DE & $56.1 \mathrm{~A}$ & $57.2 \mathrm{~A}$ & $48.2 \mathrm{~A}$ & $33.3 \mathrm{E}$ & $59.8 \mathrm{~B}$ & $61.5 \mathrm{~A}$ & $51.5 \mathrm{~A}$ \\
\hline Mean B & $26.3 \mathrm{C}$ & $44.8 \mathrm{~B}$ & $52.4 \mathrm{~A}$ & & $26.4 \mathrm{C}$ & $46.6 \mathrm{~B}$ & $54.7 \mathrm{~A}$ & \\
\hline
\end{tabular}


Table 5. Effect of different applied nitrogen and compost levels on head fresh weight for iceberg lettuce plants during the 2006 and 2007seasons.

\begin{tabular}{|c|c|c|c|c|c|c|c|c|}
\hline \multirow{3}{*}{$\begin{array}{c}\text { Nitrogen } \\
\text { levels } \\
\text { Compost } \\
\end{array}$} & \multicolumn{4}{|c|}{2006 season } & \multicolumn{4}{|c|}{2007 season } \\
\hline & $\begin{array}{c}50 \\
\mathrm{ppm}\end{array}$ & 100ppm & $150 \mathrm{ppm}$ & $\begin{array}{c}\text { Mean } \\
\mathrm{A} \\
\end{array}$ & $\begin{array}{r}50 \\
\mathrm{ppm}\end{array}$ & 100ppm & $150 \mathrm{ppm}$ & $\begin{array}{c}\text { Mean } \\
\mathrm{A} \\
\end{array}$ \\
\hline & \multicolumn{4}{|c|}{ Head fresh weight $(\mathrm{g})$} & \multicolumn{4}{|c|}{ Head fresh weight $(\mathrm{g})$} \\
\hline $0 \%$ & $230 \mathrm{H}$ & $275 \mathrm{~F}$ & $344 \mathrm{D}$ & $283 \mathrm{C}$ & $240 \mathrm{D}$ & $287 \mathrm{C}$ & $359 \mathrm{BC}$ & $295 \mathrm{C}$ \\
\hline $2 \%$ & $261 \mathrm{G}$ & $351 \mathrm{D}$ & $382 \mathrm{C}$ & $331 \mathrm{~B}$ & $272 \mathrm{C}$ & 366 B & 368 B & $335 \mathrm{~B}$ \\
\hline $4 \%$ & $291 \mathrm{E}$ & $422 \mathrm{~B}$ & $442 \mathrm{~A}$ & $385 \mathrm{~A}$ & $280 \mathrm{C}$ & $407 \mathrm{AB}$ & $426 \mathrm{~A}$ & $371 \mathrm{~A}$ \\
\hline Mean B & $260 \mathrm{C}$ & $349 \mathrm{~B}$ & $389 \mathrm{~A}$ & & $264 \mathrm{C}$ & $353 \mathrm{~B}$ & $384 \mathrm{~A}$ & \\
\hline
\end{tabular}

Table 6. Effect of different applied nitrogen and compost levels on plant fresh weight for romaine lettuce plants during the 2006 and 2007seasons.

\begin{tabular}{|r|c|c|c|c|c|c|c|c|}
\hline \multirow{2}{*}{$\begin{array}{r}\text { Nitrogen } \\
\text { levels }\end{array}$} & \multicolumn{5}{|c|}{2006 season } & \multicolumn{4}{c|}{2007 season } & \\
\cline { 2 - 9 } \\
Compost
\end{tabular}

Table 7. Effect of different applied nitrogen and compost levels on nitrogen use efficiency of leaves for iceberg lettuce plants during the 2006 and 2007seasons.

\begin{tabular}{|r|c|c|c|c|c|c|c|c|}
\hline \multirow{2}{*}{$\begin{array}{r}\text { Nitrogen } \\
\text { levels }\end{array}$} & \multicolumn{4}{|c|}{2006 season } & \multicolumn{4}{c|}{ 2007 season } \\
\cline { 2 - 10 } \\
\cline { 2 - 10 } \\
\cline { 2 - 10 } \\
\hline
\end{tabular}


Table 8. Effect of different applied nitrogen and compost levels on nitrogen use efficiency of leaves for romaine lettuce plants during the 2006 and 2007seasons.

\begin{tabular}{|c|c|c|c|c|c|c|c|c|}
\hline \multirow{3}{*}{$\begin{array}{l}\text { Nitrogen } \\
\text { levels }\end{array}$} & \multicolumn{4}{|c|}{2006 season } & \multicolumn{4}{|c|}{2007 season } \\
\hline & $\begin{array}{c}50 \\
\mathrm{ppm}\end{array}$ & 100ppm & $\begin{array}{l}150 \\
\mathrm{pm}\end{array}$ & Mean A & 50ppm & 100ppm & $\begin{array}{l}150 \\
\mathrm{ppm}\end{array}$ & Mean A \\
\hline & \multicolumn{4}{|c|}{ NUE } & \multicolumn{4}{|c|}{ NUE } \\
\hline $0 \%$ & $39.0 \mathrm{E}$ & $30.2 \mathrm{G}$ & $27.5 \mathrm{H}$ & $32.2 \mathrm{C}$ & $37.5 \mathrm{D}$ & $29.0 \mathrm{E}$ & $26.5 \mathrm{~F}$ & $31.0 \mathrm{C}$ \\
\hline $2 \%$ & $48.9 \mathrm{C}$ & $41.9 \mathrm{D}$ & $34.1 \mathrm{~F}$ & $41.6 \mathrm{~B}$ & $47.1 \mathrm{C}$ & $44.6 \mathrm{CD}$ & $\begin{array}{c}36.3 \\
D E\end{array}$ & $42.7 \mathrm{~B}$ \\
\hline $4 \%$ & $57.7 \mathrm{~A}$ & $51.7 \mathrm{~B}$ & $35.1 \mathrm{~F}$ & $48.2 \mathrm{~A}$ & $54.9 \mathrm{~A}$ & $50.6 \mathrm{~B}$ & $37.4 \mathrm{D}$ & $47.6 \mathrm{~A}$ \\
\hline Mean B & $48.5 \mathrm{~A}$ & $41.2 \mathrm{~B}$ & $32.2 \mathrm{C}$ & & $46.5 \mathrm{~A}$ & $41.4 \mathrm{~B}$ & $33.4 \mathrm{C}$ & \\
\hline
\end{tabular}

Table 9. Effect of different applied nitrogen and compost levels on $\mathrm{N}, \mathrm{P}, \mathrm{K}, \mathrm{Ca}, \mathrm{Mg}$ and NO3 of leaves for iceberg lettuce plants during the 2006 and 2007seasons

\begin{tabular}{|c|c|c|c|c|c|c|c|c|}
\hline \multirow{3}{*}{$\begin{array}{c}\text { Nitrogen } \\
\text { levels } \\
\text { Compost }\end{array}$} & \multicolumn{4}{|c|}{2006 season } & \multicolumn{4}{|c|}{2007 season } \\
\hline & $50 \mathrm{ppm}$ & $100 \mathrm{ppm}$ & $150 \mathrm{ppm}$ & Mean A & $50 \mathrm{ppm}$ & $100 \mathrm{ppm}$ & $150 \mathrm{ppm}$ & Mean A \\
\hline & \multicolumn{4}{|c|}{$\mathrm{N} \%$} & \multicolumn{4}{|c|}{$\mathrm{N} \%$} \\
\hline $0 \%$ & $1.91 \mathrm{~F}$ & $2.44 \mathrm{D}$ & $2.83 \mathrm{BC}$ & $2.36 \mathrm{C}$ & $1.96 \mathrm{H}$ & $2.53 \mathrm{E}$ & $2.94 \mathrm{C}$ & $2.47 \mathrm{C}$ \\
\hline $2 \%$ & $2.14 \mathrm{E}$ & $2.63 \mathrm{C}$ & $2.90 \mathrm{~B}$ & $2.55 \mathrm{~B}$ & $2.17 \mathrm{G}$ & $2.75 \mathrm{D}$ & $3.13 \mathrm{~B}$ & $2.68 \mathrm{~B}$ \\
\hline $4 \%$ & $2.32 \mathrm{D}$ & $2.81 \mathrm{BC}$ & $3.15 \mathrm{~A}$ & $2.73 \mathrm{~A}$ & $2.34 \mathrm{~F}$ & $2.92 \mathrm{C}$ & $3.36 \mathrm{~A}$ & $2.87 \mathrm{~A}$ \\
\hline \multirow[t]{2}{*}{ Mean B } & $2.12 \mathrm{C}$ & $2.62 \mathrm{~B}$ & $2.93 \mathrm{~A}$ & & $2.16 \mathrm{C}$ & $2.73 \mathrm{~B}$ & $3.14 \mathrm{~A}$ & \\
\hline & \multicolumn{4}{|c|}{$\mathrm{P} \%$} & \multicolumn{4}{|c|}{$\mathrm{P} \%$} \\
\hline $0 \%$ & $0.33 \mathrm{H}$ & $0.36 \mathrm{G}$ & $0.38 \mathrm{~F}$ & $0.35 \mathrm{C}$ & $0.34 \mathrm{G}$ & $0.37 \mathrm{~F}$ & $0.39 \mathrm{E}$ & $0.36 \mathrm{C}$ \\
\hline $2 \%$ & $0.35 \mathrm{GH}$ & $0.41 \mathrm{E}$ & $0.46 \mathrm{C}$ & $0.41 \mathrm{~B}$ & $0.36 \mathrm{FG}$ & $0.42 \mathrm{D}$ & $0.44 \mathrm{C}$ & $0.41 \mathrm{~B}$ \\
\hline $4 \%$ & $0.44 \mathrm{D}$ & $0.48 \mathrm{~B}$ & $0.55 \mathrm{~A}$ & $0.49 \mathrm{~A}$ & $0.38 \mathrm{G}$ & $0.46 \mathrm{~B}$ & $0.53 \mathrm{~A}$ & $0.45 \mathrm{~A}$ \\
\hline \multirow[t]{2}{*}{ Mean B } & $0.37 \mathrm{C}$ & $0.41 \mathrm{~B}$ & $0.46 \mathrm{~A}$ & & $0.36 \mathrm{C}$ & $0.41 \mathrm{~B}$ & $0.45 \mathrm{~A}$ & \\
\hline & \multicolumn{4}{|c|}{$\mathrm{K} \%$} & \multicolumn{4}{|c|}{$\mathrm{K} \%$} \\
\hline $0 \%$ & $1.77 \mathrm{H}$ & $1.89 \mathrm{G}$ & $2.05 \mathrm{~F}$ & $1.90 \mathrm{C}$ & $1.84 \mathrm{I}$ & $1.97 \mathrm{H}$ & $2.14 \mathrm{G}$ & $1.98 \mathrm{C}$ \\
\hline $2 \%$ & $2.15 \mathrm{E}$ & $2.27 \mathrm{D}$ & $2.40 \mathrm{C}$ & $2.27 \mathrm{~B}$ & $2.24 \mathrm{~F}$ & $2.36 \mathrm{C}$ & $2.31 \mathrm{D}$ & $2.30 \mathrm{~B}$ \\
\hline $4 \%$ & $2.35 \mathrm{CD}$ & $2.61 \mathrm{~B}$ & $2.73 \mathrm{~A}$ & $2.56 \mathrm{~A}$ & $2.26 \mathrm{E}$ & $2.51 \mathrm{~B}$ & $2.63 \mathrm{~A}$ & $2.46 \mathrm{~A}$ \\
\hline \multirow[t]{2}{*}{ Mean B } & $2.09 \mathrm{C}$ & $2.25 \mathrm{~B}$ & $2.39 \mathrm{~A}$ & & $2.11 \mathrm{C}$ & $2.28 \mathrm{~B}$ & $2.36 \mathrm{~A}$ & \\
\hline & \multicolumn{4}{|c|}{ Сa \% } & \multicolumn{4}{|c|}{$\mathrm{Ca} \%$} \\
\hline $0 \%$ & $0.51 \mathrm{~F}$ & $0.59 \mathrm{E}$ & $0.66 \mathrm{D}$ & $0.59 \mathrm{C}$ & $0.53 \mathrm{G}$ & $0.61 \mathrm{~F}$ & $0.68 \mathrm{E}$ & $0.61 \mathrm{C}$ \\
\hline $2 \%$ & $0.72 \mathrm{CD}$ & $0.74 \mathrm{C}$ & $0.79 \mathrm{BC}$ & $0.75 \mathrm{~B}$ & $0.75 \mathrm{D}$ & $0.77 \mathrm{C}$ & $0.76 \mathrm{CD}$ & $0.76 \mathrm{~B}$ \\
\hline $4 \%$ & $0.81 \mathrm{~B}$ & $0.85 \mathrm{AB}$ & $0.89 \mathrm{~A}$ & $0.85 \mathrm{~A}$ & $0.78 \mathrm{BC}$ & $0.80 \mathrm{~B}$ & $0.85 \mathrm{~A}$ & $0.81 \mathrm{~A}$ \\
\hline \multirow[t]{2}{*}{ Mean B } & $0.68 \mathrm{~A}$ & $0.72 \mathrm{~B}$ & $0.78 \mathrm{C}$ & & $0.68 \mathrm{C}$ & $0.72 \mathrm{~B}$ & $0.76 \mathrm{~A}$ & \\
\hline & \multicolumn{4}{|c|}{$\mathrm{Mg} \%$} & \multicolumn{4}{|c|}{$\mathrm{Mg} \%$} \\
\hline $0 \%$ & $0.18 \mathrm{~F}$ & $0.21 \mathrm{E}$ & $0.24 \mathrm{D}$ & $0.21 \mathrm{C}$ & $0.18 \mathrm{E}$ & $0.21 \mathrm{D}$ & $0.25 \mathrm{C}$ & $0.21 \mathrm{C}$ \\
\hline $2 \%$ & $0.26 \mathrm{CD}$ & $0.27 \mathrm{C}$ & $0.28 \mathrm{~B}$ & $0.27 \mathrm{~B}$ & $0.27 \mathrm{BC}$ & $0.28 \mathrm{~B}$ & $0.27 \mathrm{BC}$ & $0.27 \mathrm{~B}$ \\
\hline $4 \%$ & $0.29 \mathrm{~B}$ & $0.31 \mathrm{~A}$ & $0.32 \mathrm{~A}$ & $0.31 \mathrm{~A}$ & $0.27 \mathrm{BC}$ & $0.29 \mathrm{AB}$ & $0.30 \mathrm{~A}$ & $0.29 \mathrm{~A}$ \\
\hline \multirow[t]{2}{*}{ Mean B } & $0.24 \mathrm{C}$ & $0.26 \mathrm{~B}$ & $0.28 \mathrm{~A}$ & & $0.24 \mathrm{~B}$ & $0.26 \mathrm{AB}$ & $0.27 \mathrm{~A}$ & \\
\hline & \multicolumn{4}{|c|}{$\mathrm{NO}_{3} \mathrm{ppm}$} & \multicolumn{4}{|c|}{$\mathrm{NO}_{3} \mathrm{ppm}$} \\
\hline $0 \%$ & $527 \mathrm{~F}$ & $723 \mathrm{D}$ & $1055 \mathrm{~B}$ & $768 \mathrm{~B}$ & $495 \mathrm{H}$ & $712 \mathrm{E}$ & $1060 \mathrm{C}$ & $764 \mathrm{~B}$ \\
\hline $2 \%$ & $544 \mathrm{EF}$ & $738 \mathrm{CD}$ & $1120 A B$ & $800 \mathrm{AB}$ & $549 \mathrm{G}$ & $731 \mathrm{DE}$ & $1105 \mathrm{~B}$ & $791 \mathrm{AB}$ \\
\hline $4 \%$ & $581 \mathrm{E}$ & $774 \mathrm{C}$ & $1155 \mathrm{~A}$ & $828 \mathrm{~A}$ & $589 \mathrm{~F}$ & $767 \mathrm{D}$ & $1148 \mathrm{~A}$ & $821 \mathrm{~A}$ \\
\hline Mean B & $541 \mathrm{C}$ & $745 \mathrm{~B}$ & $1110 \mathrm{~A}$ & & $536 \mathrm{C}$ & $736 \mathrm{~B}$ & $1104 \mathrm{~A}$ & \\
\hline
\end{tabular}


Table 10. Effect of different applied nitrogen and compost levels on $\mathrm{N}, \mathrm{P}, \mathrm{K}, \mathrm{Ca}, \mathrm{Mg}$ and NO3 of leaves for romaine lettuce plants during the 2006 and 2007seasons.

\begin{tabular}{|c|c|c|c|c|c|c|c|c|}
\hline \multirow{3}{*}{$\begin{array}{r}\begin{array}{r}\text { Nitrogen } \\
\text { levels }\end{array} \\
\text { Compost }\end{array}$} & \multicolumn{4}{|c|}{2006 season } & \multicolumn{4}{|c|}{2007 season } \\
\hline & $50 \mathrm{ppm}$ & 100ppm & 150 ppm & Mean A & $\begin{array}{c}50 \\
\mathrm{ppm}\end{array}$ & $100 \mathrm{ppm}$ & $150 \mathrm{ppm}$ & Mean A \\
\hline & \multicolumn{4}{|c|}{$\mathrm{N} \%$} & \multicolumn{4}{|c|}{$\mathrm{N} \%$} \\
\hline $0 \%$ & $2.12 \mathrm{~F}$ & $2.68 \mathrm{D}$ & $3.13 B C$ & $2.64 \mathrm{C}$ & $2.06 \mathrm{H}$ & $2.66 \mathrm{E}$ & $3.09 \mathrm{C}$ & $2.60 \mathrm{C}$ \\
\hline $2 \%$ & $2.35 \mathrm{E}$ & $2.91 \mathrm{C}$ & $3.24 \mathrm{~B}$ & $2.83 \mathrm{~B}$ & $2.28 \mathrm{G}$ & $2.89 \mathrm{D}$ & $3.29 \mathrm{~B}$ & $2.81 \mathrm{~B}$ \\
\hline $4 \%$ & 2.57DE & $3.14 \mathrm{BC}$ & $3.47 \mathrm{~A}$ & $3.06 \mathrm{~A}$ & $2.46 \mathrm{~F}$ & $3.06 \mathrm{C}$ & $3.52 \mathrm{~A}$ & $3.01 \mathrm{~A}$ \\
\hline \multirow[t]{2}{*}{ Mean B } & $2.35 \mathrm{C}$ & $2.91 \mathrm{~B}$ & $3.28 \mathrm{~A}$ & & $2.26 \mathrm{C}$ & $2.87 \mathrm{~B}$ & $3.30 \mathrm{~A}$ & \\
\hline & \multicolumn{4}{|c|}{$\mathrm{P} \%$} & \multicolumn{4}{|c|}{$\mathrm{P} \%$} \\
\hline $0 \%$ & $0.36 \mathrm{~F}$ & $0.40 \mathrm{DE}$ & $0.42 \mathrm{D}$ & $0.39 \mathrm{C}$ & $0.35 \mathrm{G}$ & $0.38 \mathrm{~F}$ & $0.41 \mathrm{E}$ & $0.38 \mathrm{C}$ \\
\hline $2 \%$ & $0.39 \mathrm{E}$ & $0.45 \mathrm{CD}$ & $0.51 B C$ & $0.45 \mathrm{~B}$ & $\begin{array}{c}0.37 \\
F G\end{array}$ & $0.48 \mathrm{D}$ & $0.54 \mathrm{C}$ & $0.46 \mathrm{~B}$ \\
\hline $4 \%$ & $0.49 \mathrm{C}$ & $0.53 \mathrm{~B}$ & $0.61 \mathrm{~A}$ & $0.54 \mathrm{~A}$ & $\begin{array}{c}0.52 \\
C D \\
\end{array}$ & $0.57 \mathrm{~B}$ & $0.65 \mathrm{~A}$ & $0.58 \mathrm{~A}$ \\
\hline \multirow[t]{2}{*}{ Mean B } & $0.41 \mathrm{C}$ & $0.46 \mathrm{~B}$ & $0.51 \mathrm{~A}$ & & $0.41 \mathrm{C}$ & $0.48 \mathrm{~B}$ & $0.53 \mathrm{~A}$ & \\
\hline & \multicolumn{4}{|c|}{$\mathrm{K} \%$} & \multicolumn{4}{|c|}{$\mathrm{K} \%$} \\
\hline $0 \%$ & $0.26 \mathrm{H}$ & $0.31 \mathrm{G}$ & $0.34 \mathrm{~F}$ & $0.30 \mathrm{C}$ & $0.25 \mathrm{H}$ & $0.30 \mathrm{G}$ & $0.33 \mathrm{~F}$ & $0.29 \mathrm{C}$ \\
\hline $2 \%$ & $0.38 \mathrm{DE}$ & $0.39 \mathrm{D}$ & $0.42 \mathrm{C}$ & $0.40 \mathrm{~B}$ & $0.36 \mathrm{E}$ & $0.41 \mathrm{D}$ & $0.44 \mathrm{CD}$ & $0.40 \mathrm{~B}$ \\
\hline $4 \%$ & $0.37 \mathrm{E}$ & $0.44 \mathrm{~B}$ & $0.47 \mathrm{~A}$ & $0.43 \mathrm{~A}$ & $0.45 \mathrm{C}$ & $0.47 \mathrm{~B}$ & $0.52 \mathrm{~A}$ & $0.48 \mathrm{~A}$ \\
\hline \multirow[t]{2}{*}{ Mean B } & $0.34 \mathrm{C}$ & $0.38 \mathrm{~B}$ & $0.41 \mathrm{~A}$ & & $0.35 \mathrm{C}$ & $0.39 \mathrm{~B}$ & $0.43 \mathrm{~A}$ & \\
\hline & \multicolumn{4}{|c|}{$\mathrm{Ca} \%$} & \multicolumn{4}{|c|}{ Ca \% } \\
\hline $0 \%$ & $0.57 \mathrm{H}$ & $0.67 \mathrm{G}$ & $0.74 \mathrm{~F}$ & $0.66 \mathrm{C}$ & $0.55 \mathrm{H}$ & $0.64 \mathrm{G}$ & $0.71 \mathrm{~F}$ & $0.63 \mathrm{C}$ \\
\hline $2 \%$ & $0.81 \mathrm{E}$ & $0.83 \mathrm{DE}$ & $0.88 \mathrm{C}$ & $0.84 \mathrm{~B}$ & $0.78 \mathrm{E}$ & $0.89 \mathrm{D}$ & $0.94 \mathrm{CD}$ & $0.87 \mathrm{~B}$ \\
\hline $4 \%$ & $0.85 \mathrm{D}$ & $0.95 \mathrm{~B}$ & $1.06 \mathrm{~A}$ & $0.95 \mathrm{~A}$ & $0.97 \mathrm{C}$ & $1.02 \mathrm{~B}$ & $1.07 \mathrm{~A}$ & $1.02 \mathrm{~A}$ \\
\hline \multirow[t]{2}{*}{ Mean B } & $0.74 \mathrm{C}$ & $0.87 \mathrm{~B}$ & $0.89 \mathrm{~A}$ & & $0.77 \mathrm{C}$ & $0.85 \mathrm{~B}$ & $0.91 \mathrm{~A}$ & \\
\hline & \multicolumn{4}{|c|}{$\mathrm{Mg} \%$} & \multicolumn{4}{|c|}{$\mathrm{Mg} \%$} \\
\hline $0 \%$ & $0.20 \mathrm{G}$ & $0.24 \mathrm{~F}$ & $0.27 \mathrm{E}$ & $0.24 \mathrm{C}$ & $0.20 \mathrm{H}$ & $0.23 \mathrm{G}$ & $0.26 \mathrm{~F}$ & $0.23 \mathrm{C}$ \\
\hline $2 \%$ & $0.29 \mathrm{DE}$ & $0.30 \mathrm{D}$ & $0.32 \mathrm{C}$ & $0.30 \mathrm{~B}$ & $0.28 \mathrm{E}$ & $0.32 \mathrm{D}$ & $0.34 \mathrm{CD}$ & $0.31 \mathrm{~B}$ \\
\hline $4 \%$ & $0.33 \mathrm{BC}$ & $0.34 \mathrm{~B}$ & $0.36 \mathrm{~A}$ & $0.34 \mathrm{~A}$ & $0.35 \mathrm{C}$ & $0.37 \mathrm{~B}$ & $0.39 \mathrm{~A}$ & $0.37 \mathrm{~A}$ \\
\hline \multirow[t]{2}{*}{ Mean B } & $0.27 \mathrm{C}$ & $0.29 \mathrm{~B}$ & $0.32 \mathrm{~A}$ & & $0.28 \mathrm{C}$ & $0.31 \mathrm{~B}$ & $0.33 \mathrm{~A}$ & \\
\hline & \multicolumn{4}{|c|}{$\mathrm{NO}_{3} \mathrm{ppm}$} & \multicolumn{4}{|c|}{$\mathrm{NO}_{3} \mathrm{ppm}$} \\
\hline $0 \%$ & $549 \mathrm{I}$ & $772 \mathrm{~F}$ & $1160 \mathrm{C}$ & $845 \mathrm{~B}$ & $560 \mathrm{H}$ & $799 \mathrm{~F}$ & $1122 \mathrm{C}$ & $817 \mathrm{~B}$ \\
\hline $2 \%$ & $588 \mathrm{H}$ & $812 \mathrm{E}$ & $1232 \mathrm{~B}$ & $880 \mathrm{AB}$ & $586 \mathrm{H}$ & $785 \mathrm{E}$ & $1191 \mathrm{~B}$ & $851 A B$ \\
\hline $4 \%$ & $639 \mathrm{G}$ & $852 \mathrm{D}$ & $1270 \mathrm{~A}$ & $910 \mathrm{~A}$ & $654 \mathrm{G}$ & $864 \mathrm{D}$ & $1242 \mathrm{~A}$ & $880 \mathrm{~A}$ \\
\hline Mean B & $596 \mathrm{C}$ & $819 \mathrm{~B}$ & $1221 \mathrm{~A}$ & & $576 \mathrm{C}$ & $792 \mathrm{~B}$ & $1180 \mathrm{~A}$ & \\
\hline
\end{tabular}


Fig. 1. Relationship between iceberg lettuce yield and nitrate content of leaves 2006 season.

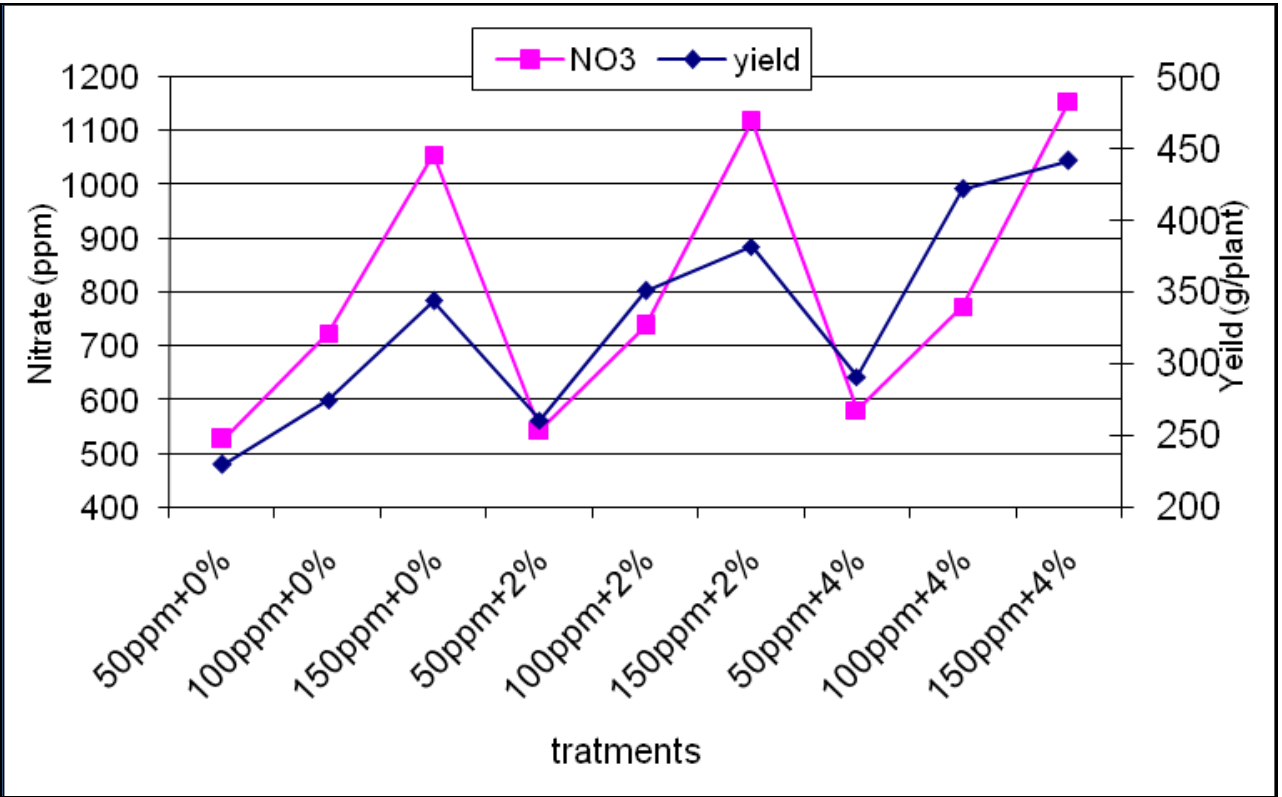

Fig. 2. Relationship between iceberg lettuce yield and nitrate content of leaves 2007 season.

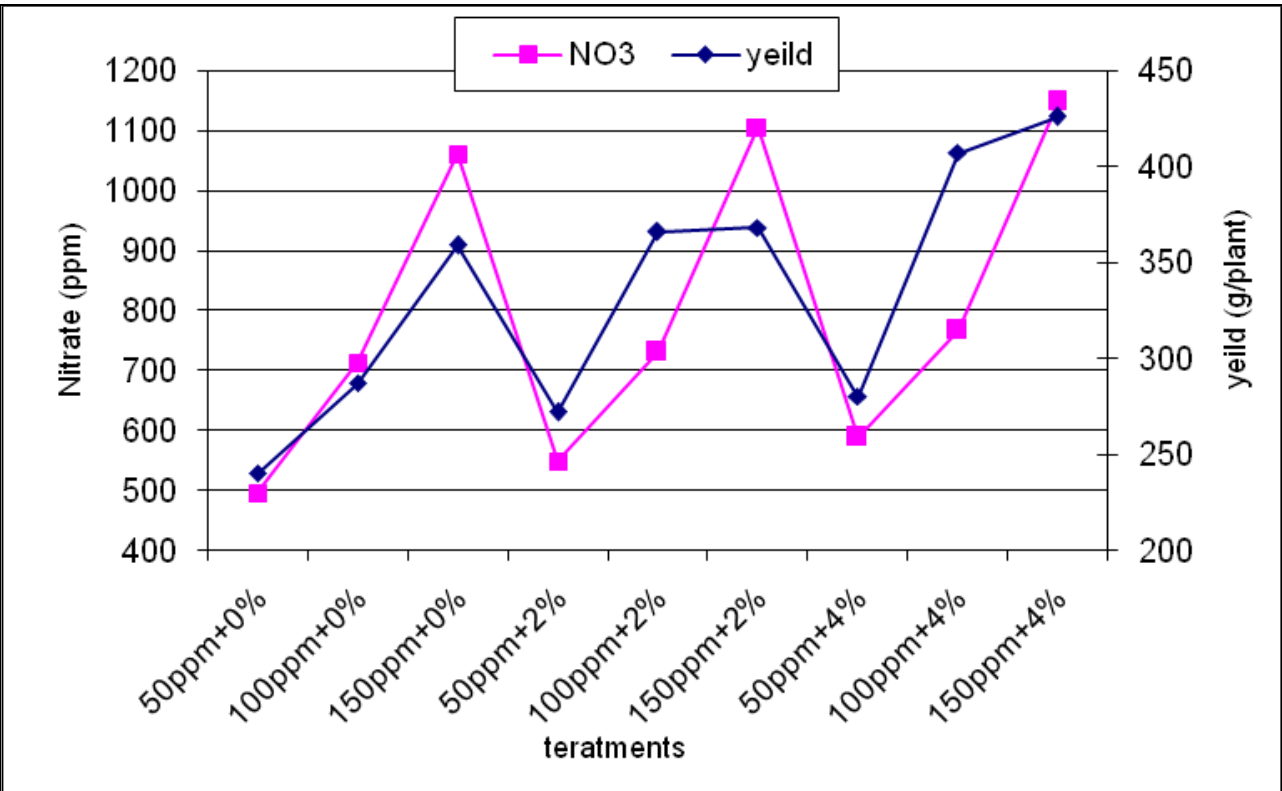


Fig. 3. Relationship between romaine lettuce yield and nitrate content of leaves 2006season.

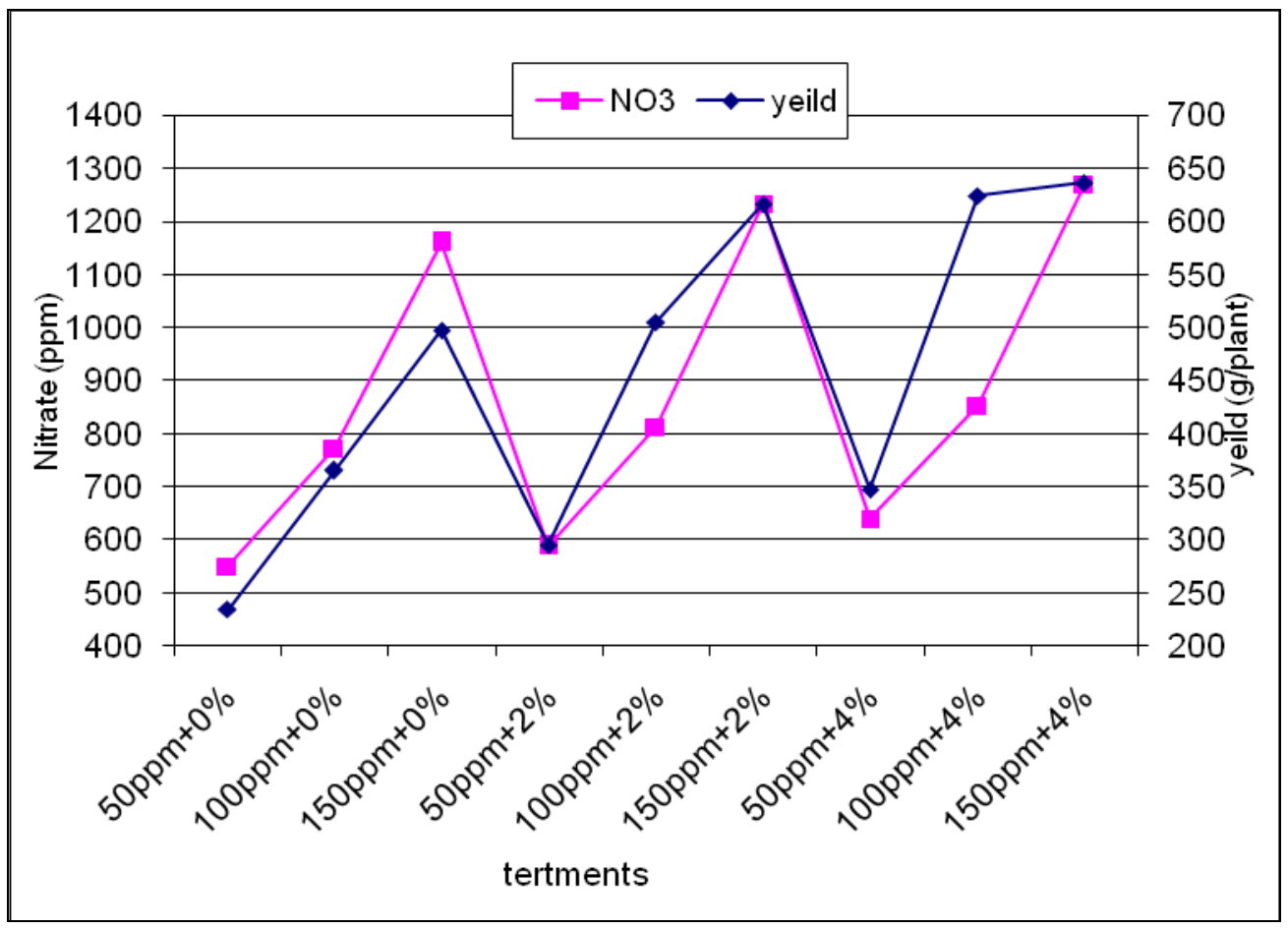

Fig. 4. Relationship between romaine lettuce yield and nitrate content of leaves 2007 season.

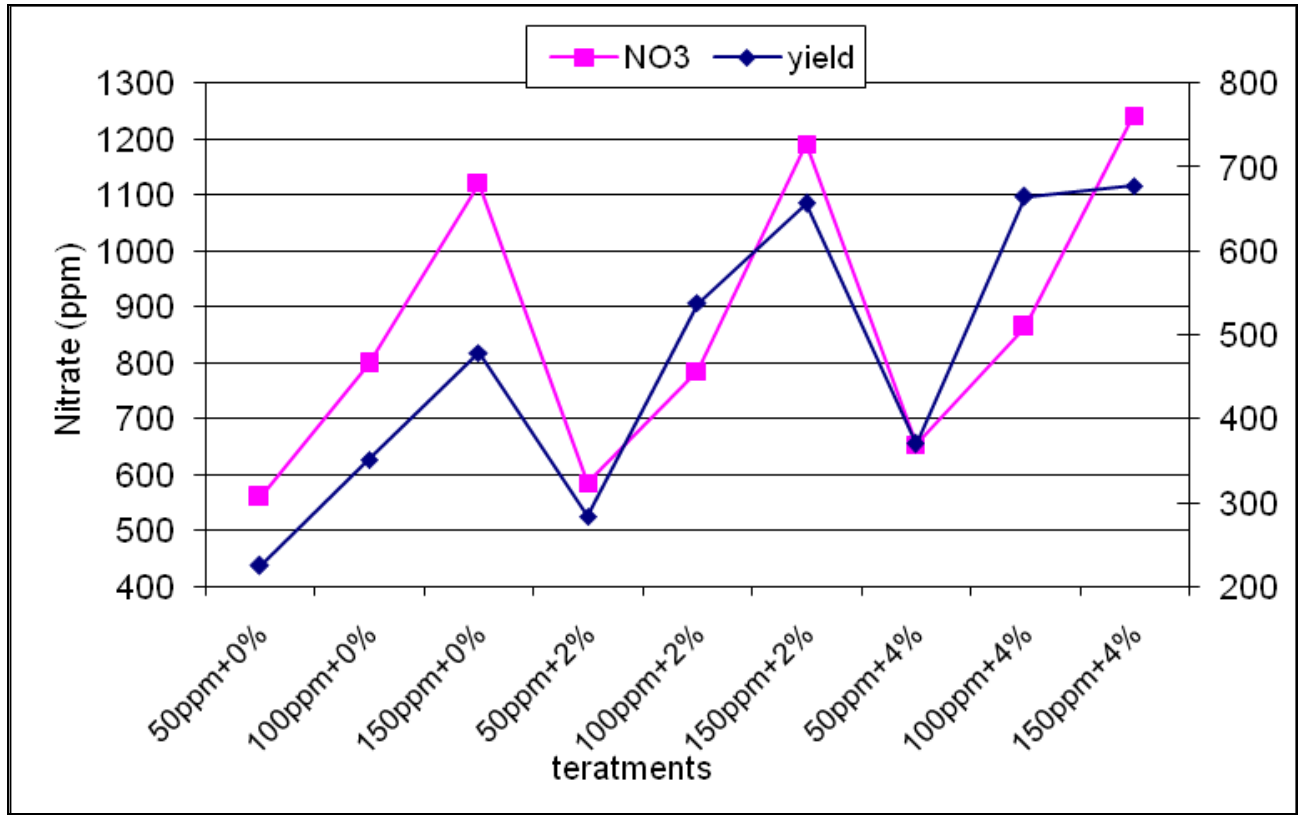




\section{REFERENCES}

1. Abd-Elmoniem, E. M., M. Z. El-Shinawy, A. F. Abou-Hadid and Y. I. Helmy. 2001. Response of lettuce plant to feeding with unconventional sources under hydroponic system. Acta Hort. 559: 549-554.

2. Abu-Rayyan, A., B. H. Kharawish and K. Al-Ismail. 2004. Nitrate content in lettuce (Lactuca sativa L.) heads in relation to plant spacing, nitrogen form and irrigation level. J. Sci. Food Agric. 84, 931-936.

3. Alphonse, M. and E. M. Saad. 2000. Growing greenhouse cucumber in farmyard and chicken manure media in combination with foliar application of zinc, manganese and boron. Egypt. J. Hort. 27: 315- 336.

4. Bremner, J. M. and C. S. Mulvaney. 1982. Nitrogen-Total. Pages595-624 in A. L. Page, R. H. Miller and D. R. Keeny, editors. Methods of soil analysis. Part 2. Chemical and microbiological properties, 2ndedition. Number 9 in the series Agronomy. American Society of Agronomy and Soil Science Society of America, Inc.,Madison, Wisconsin.

5. Broadley M. R., A. J. E. GutieÂrrez, A. Burns and I. G. Burns. 2000. What are the effects of nitrogen deficiency on growth components of lettuce. New Phytologist 147, 519-526.

6. Byrne C., M. J. Maher and M. J. Hennerty. 2001. Reducing the nitrogen content of protected lettuce crops. Irish Journal of Agricultural \& Food Research: 39 :491498.

7. Chapman, H. D. and P. F. Pratt. 1961. Methods of analysis for soil, plant, and water. University of California, Division of Agric Sci.

8. Gul, A., O”ztan, F., Erog “ ul, D., Yag`mur B., and A. R. Ongun. 2003. The use of organic manure for iceberg lettuce plants grown in substrates. Acta Hort. 608, 5357.

9. Marschner H. 1995. Mineral nutrition of higher plant. New York: Academic Press. 889p.

10. Pinheiro-Henriques A. R. and F. M. Marcellis. 2000. Regulation of growth at steady-state nitrogen nutrition in lettuce (Lactuca sativa L.): interactive effects of nitrogen and irradiance. Annals of Botany 86: 1073-1080.

11. Pons T. L. and M. H. M westbeek. 2004. Analysis of differences in photosynthetic nitrogen-use efficiency between four contrasting species. Physiologia Plantarum 122: $68-78$.

12. Pôrto M. L., C. A. ailson, P. S., C. A. Raunira and A. A. Jandeilson. 2008. Nitrate production and accumulation in lettuce as affected by mineral nitrogen supply and organic fertilization. Hortic. bras., 26 (2) : $227-230$ 
13. Santamaria, P., A. Elia, G. Papa and F. Serio. 2002. Effect of solution nitrogen concentration on yield, leaf element content, and water and nitrogen use efficiency of three hydroponically-grown rocket salad genotypes. Plants. J. Plant Nutr. 25, 245-258.

14. Waller, R. A. and D. B. Duncan. 1969. Ways for the symmetric multiple comparison. Problem. Amer. Stat. Assoc J. 19: 1485-1503.

15. Yuri, J. E., M. C. G. DeRodrigues and J. Juarez. 2004. Effect of organic compost on crisp head lettuce production and commercial characteristics. Hortic. Bras., 22, 127-130.

16. Zhu Z. J., A. S. gerend and B. Sattelmacher. 2000. Influence of nitrate and urea supply on growth and nitrate accumulation in hydroponically grown lettuce (Lactuca sativa). Xth International Colloquium for the Optimization of Plant Nutrition. April 8-13 2000, Cairo Sheraton, Cairo, Egypt. 


\title{
أدارة عنصر النيتروجين تحت مستويات مختلفة من الكمبوست لنباتات الخس النامية في بيئة ليف جوز الهند
}

\author{
احمد عوني احمد فرج' ، محمد عبدربه احمد' ، عصام محمد عبدالمنعم ' \\ ا ـ المعدل المركزي للمناخ الزراعي، مركز البحوث الزراعية، اللقي - جيزة \\ r ـ قسم الاراضس، كلبة الزراعة، جامعة عبن شمس القاهرة
}

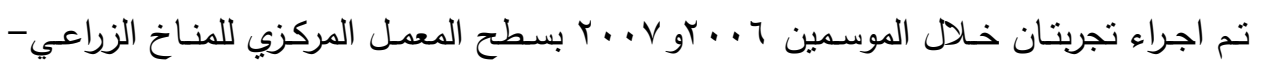

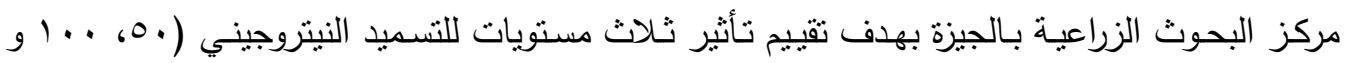

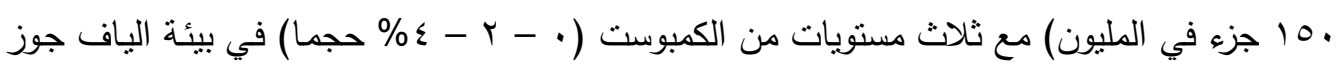

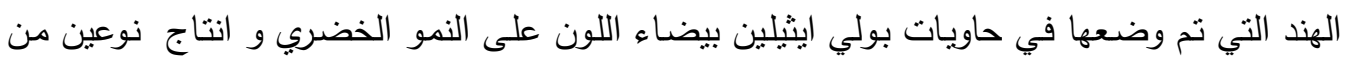

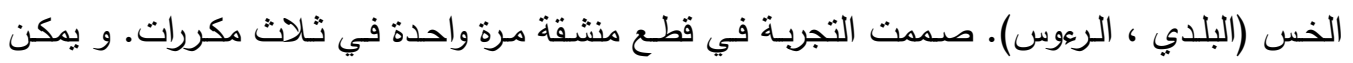

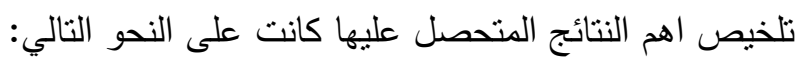

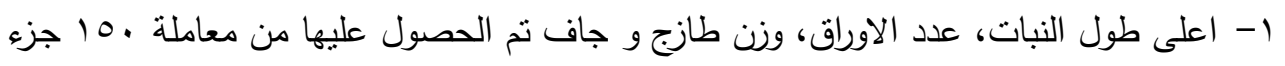
في المليون مع ؛ \% كمبوست. ץ- اعطت معاملة ـ10 جزء في المليون اعلى محتوى لـلاوراق من النترات مـع المستويات المختلفة من الكمبوست. r- اعطت معاملة ـ0 جزء في المليون نيتروجين اعلى كفاءة استخدام لمياه النتيروجين (NUE)

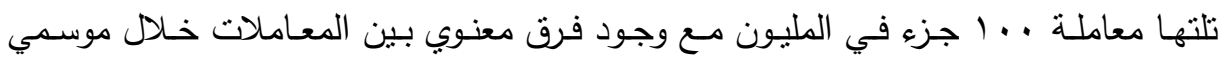
الزراعة. بما يؤكد اهمية الاستخدام الامتل للتسميد النيتروجيني في انتاجية نباتات الخس للمحافظة على 